\title{
MISMATCH NEGATIVITY IN CHILDHOOD TEMPORAL LOBE EPILEPSY: A PROPOSED PARADIGM FOR TESTING CENTRAL AUDITORY PROCESSING
}

\author{
David Tomé ${ }^{1,2}$, Pedro Moreira ${ }^{1,3}$, João Marques-Teixeira ${ }^{1}$, Fernando Barbosa ${ }^{1}$, \\ Satu Jääskeläinen ${ }^{4}$ \\ ${ }^{1}$ Laboratory of Neuropsychophysiology, Faculty of Psychology and Educational Sciences, University of Porto, \\ Portugal \\ ${ }^{2}$ Department of Audiology, School of Allied Health Sciences, Polytechnic Institute of Porto, 4400-330 V.N. Gaia, \\ Portugal \\ ${ }^{3}$ School of Criminology, Faculty of Law, University of Porto, Portugal \\ ${ }^{4}$ Department of Clinical Neurophysiology, University of Turku, Finland
}

Corresponding author: David Tomé, Laboratory of Neuropsychophysiology, Faculty of Psychology and Educational Sciences, University of Porto, Portugal, Tel.: +351 939591301; Fax: +351 222061001, e-mail: dts@estsp.ipp.pt

\begin{abstract}
Background: Temporal lobe epilepsy (TLE) is a neurological disorder that directly affects cortical areas responsible for auditory processing. The resulting abnormalities can be assessed using event-related potentials (ERP), which have high temporal resolution. However, little is known about TLE in terms of dysfunction of early sensory memory encoding or possible correlations between EEGs, linguistic deficits, and seizures. Mismatch negativity (MMN) is an ERP component - elicited by introducing a deviant stimulus while the subject is attending to a repetitive behavioural task - which reflects pre-attentive sensory memory function and reflects neuronal auditory discrimination and perceptional accuracy.
\end{abstract}

Hypothesis: We propose an MMN protocol for future clinical application and research based on the hypothesis that children with TLE may have abnormal MMN for speech and non-speech stimuli. The MMN can be elicited with a passive auditory oddball paradigm, and the abnormalities might be associated with the location and frequency of epileptic seizures.

Significance: The suggested protocol might contribute to a better understanding of the neuropsychophysiological basis of MMN. We suggest that in TLE central sound representation may be decreased for speech and non-speech stimuli.

Discussion: MMN arises from a difference to speech and non-speech stimuli across electrode sites. TLE in childhood might be a good model for studying topographic and functional auditory processing and its neurodevelopment, pointing to MMN as a possible clinical tool for prognosis, evaluation, follow-up, and rehabilitation for TLE.

Keywords: temporal lobe epilepsy (TLE) • mismatch negativity $(\mathrm{MMN}) \bullet$ childhood $\bullet$ auditory processing

\section{EL MMN EN LA EPILEPSIA DEL LÓBULO TEMPORAL EN NIÑOS. EL PARADIGMA PROPUESTO DEL EXAMEN DEL PROCESAMIENTO AUDITIVO CENTRAL}

Introducción: La epilepsia del lóbulo temporal (TLE) es una enfermedad neurológica, que afecta directamente a las áreas de la corteza cerebral implicadas en el procesamiento auditivo. Los cambios en la actividad de la corteza, relacionados con la epilepsia, pueden ser evaluados a través del método de potenciales evocados (ERP), que tiene una alta resolución temporal. Poco se sabe, sin embargo, sobre la epilepsia del lóbulo temporal en cuanto a la disfuncción de la codificación en la memoria a corto plazo o en cuanto a las posibles correlaciones entre EEG, déficit verbales y convulsiones. La onda (potencial) de la incompatibilidad (MMN) es un componente de ERP - que aparece en respuesta a los estímulos raros presentados en el contexto de estímulos frecuentes e idénticos - que refleja los procesos inconscientes de diferenciación de sonidos.

Hipótesis: Proponemos la aplicación del protocolo de la onda de incompatibilidad MMN para futuros ensayos clínicos, basándonos en la tesis de que en niños con la epilepsia del lóbulo lateral puede aparecer una onda incorrecta de la incompatibilidad para los estímulos verbales y no verbales MMN puede producirse en el modelo auditivo pasivo del paradigma oddball, y los cambios en los parámetros MMN pueden ser relacionados con la localización y frecuencia de convulsiones.

Significado: El protocolo propuesto puede contribuir a una mejor comprensión de las bases neuropsicofisiológicas de MMN. Sugerimos que en la epilepsia del lóbulo temporal, la representación de sonidos en la corteza auditiva puede ser reducida para el habla y para los estímulos no verbales. 
Discusión: La onda de la incompatibilidad MMN refleja la diferencia entre los estímulos verbales y no verbales, que se puede observar en diferentes electrodos. La epilepsia del lóbulo temporal en niños puede ser un buen modelo para el estudio de la representación cortical del procesamiento auditivo y de los cambios, a los que está sujeta en el cerebro en desarrollo, y el registro de la onda de incompatibilidad MMN puede ser útil en la clínica en el proceso del diagnóstico y tratameinto de la epilepsia del lóbulo temporal.

\section{ПОТЕНЦИАЛ НЕСООТВЕТСТВИЯ В ДЕТСКОЙ ВИСОЧНОЙ ЭПИЛЕПСИИ: ПРЕДЛАГАЕМАЯ ПАРАДИГМА ИССЛЕДОВАНИЯ ЦЕНТРАЛЬНОЙ СЛУХОВОЙ ОБРАБОТКИ}

\section{Изложение}

Введение: Височная эпилепсия (TLE) - это неврологическое заболевание, которое непосредственно влияет на участки мозговой коры, задействованные в слуховой обработке. Изменения в активности коры, связанные с эпилепсией, можно оценить, используя метод вызванных потенциалов (ERP), который имеет высокое временное разрешение. Однако мало что известно о височной эпилепсии в области дисфункции кодирования в кратковременной памяти или возможных взаимосвязей между ЭЭГ, речевыми дефицитами и эпилептическими приступами. Волна (потенциал) несоответствия (MMN) - это составная часть ERP - проявляющаяся в виде реакции на редкие импульсы, презентированные на фоне частых, идентичных импульсов - отражающая предвниматильные процессы дифференциации звуков.

Гипотеза: Предлагаем использовать протокол волны несоответствия MMN в будущих клинических исследованиях, базируя на предположении, что у детей с височной эпилепсией может появиться неправильная волна несоответствия для вербальных и невербальных импульсов MMN. Она может проявиться в пассивной модели слуховой парадигмы oddball, а изменения в параметрах MMN могут быть связаны с размещением и частотой эпилептических приступов.

Значение: Указанный протокол может привести к лучшему пониманию нейропсихофизиологических оснований MMN. Мы предполагаем, что в височной эпилепсии репрезентация звуков в слуховой коре может быть пониженной для речи и невербальных импульсов.

Дискуссия: Волна несоответствия MMN отражает разницу между вербальными и невербальными импульсами, наблюдающуюся на отдельных электродах. Височная эпилепсия у детей может быть хорошей моделью ислледования корковой репрезентации слуховой обработки и изменений, которым она подвергается в развивающемся мозгу, а регистрация волны несоответствия MMN может быть полезна в клинике в процессе диагностики и терапии височной эпилепсии.

\section{POTENCJAŁ NIEZGODNOŚCI W DZIECIĘCEJ PADACZCE SKRONIOWEJ: PROPONOWANY PARADYGMAT BADANIA CENTRALNEGO PRZETWARZANIA SŁUCHOWEGO}

\section{Streszczenie}

Wstęp: Padaczka skroniowa (TLE) jest chorobą neurologiczną, która bezpośrednio wpływa na obszary kory mózgowej zaangażowane w przetwarzanie słuchowe. Zmiany w aktywności kory związane z padaczką można oceniać przy użyciu metody potencjałów wywołanych (ERP), która ma wysoką rozdzielczość czasową. Niewiele jednak wiadomo o padaczce skroniowej w zakresie dysfunkcji kodowania w pamięci krótkotrwałej czy możliwych korelacji pomiędzy EEG, deficytami językowymi i napadami padaczkowymi. Fala (potencjał) niezgodności (MMN) jest składową ERP - pojawiającą się w odpowiedzi na bodźce rzadkie prezentowane na tle częstych, identycznych bodźców - odzwierciedlającą przeduwagowe procesy różnicowania dźwięków.

Hipoteza: Proponujemy zastosowanie protokołu fali niezgodności MMN do przyszłych badań klinicznych, opierając się na założeniu, że u dzieci z padaczką skroniową może pojawić się nieprawidłowa fala niezgodności dla bodźców werbalnych i niewerbalnych MMN. Może wystąpić w biernym modelu słuchowego paradygmatu oddball, a zmiany w parametrach MMN mogą być związane z lokalizacją i częstotliwością napadów padaczkowych.

Znaczenie: Zasugerowany protokół może przyczynić się do lepszego zrozumienia neuropsychofizjologicznych podstaw MMN. Sugerujemy, że w padaczce skroniowej reprezentacja dźwięków w korze słuchowej może być zmniejszona dla mowy i bodźców niejęzykowych. 
Dyskusja: Fala niezgodności MMN odzwierciedla różnicę pomiędzy bodźcami językowymi i niejęzykowymi obserwowaną na poszczególnych elektrodach. Padaczka skroniowa u dzieci może być dobrym modelem badania korowej reprezentacji przetwarzania słuchowego i zmian, jakim ona podlega w rozwijającym się mózgu, a rejestracja fali niezgodności MMN może być przydatna w klinice w procesie diagnostyki i terapii padaczki skroniowej.

\section{Background}

Temporal lobe epilepsy (TLE) is the most frequent form of partial epilepsy in adults, and hippocampal sclerosis is the most common neuropathological finding in patients with medically refractory TLE $[1,2]$. TLE results from abnormal activity in a group of neurons that may significantly affect normal cognitive processes and behavior. TLE in childhood may be cryptogenic or have several etiologies, the most frequent being mesial temporal sclerosis, cortical dysplasia, brain injuries, extrahippocampal lesions and/or hippocampal sclerosis, always with progression and expansion to the temporal cortex [3]. Regardless of the epileptic focus, neuropsychological deficits are common among children and adults with TLE, becoming more serious with higher frequency of seizures and longer episodes [4-6].

It has been repeatedly shown that both short-term and long-term memories are impaired in TLE $[7,8]$. However, little is known concerning dysfunction of sensory memory encoding in TLE or possible correlations between EEGs, linguistic deficits, and seizures. TLE in childhood is a neurological disorder that directly affects cortical areas of the central auditory system. Thus, TLE seems to be a good model for studying topographic and functional aspects of auditory processing and underlying neurodevelopment. The use of event-related potentials (ERPs) might contribute to a better understanding of the learning difficulties that children with this disorder have and of the neuronal plasticity that epileptogenesis affects [9].

Mismatch negativity (MMN), and its magnetic equivalent $(\mathrm{MMNm})$, currently provide an objective measure of auditory perception and discrimination based on the presence of a short-term memory (sensory memory) and its associated echoic memory trace. These traces represent an ongoing aspect of repetitive stimulation, and fade within 5-10 ms of being elicited by a deviant event [10-13]. MMN can be registered in the absence of attention and with no task requirements, making it particularly suitable for studying different clinical populations, newborns, and infants [14]. Recently, several studies have pointed to MNN as a powerful tool for measuring cognitive and functional declines, central auditory abnormalities, and deficiencies in $\mathrm{N}$-methyl-D-aspartate (NMDA) receptor function [13,15-18]. The MMN is a fronto-central $(\mathrm{Fpz}, \mathrm{Fz}, \mathrm{Cz})$ negative component of the auditory event-related potential (ERP), and a positive component in mastoids (M1, M2), usually peaking 100-250 ms from stimulus onset. Its main generators are the bilateral supratemporal cortices with contributions from the frontal lobes, right parietal lobe, thalamus, and hippocampus $[12,13,15]$.

Several authors have studied MMN in epilepsy. In benign childhood epilepsy, MMN was longer or absent for speech sounds compared to controls, but for pure-tone stimuli no differences between the groups were found [19]. More recently, Miyajima et al. [20] found in adult TLE patients an enhanced frontal MMN and a reduced MMN at the mastoids to pure-tone frequency change, suggesting that frontal lobe hyperexcitability compensates for temporal lobe dysfunction. In addition, Honbolygó et al. [21] saw, in Landau-Kleffner syndrome, a MMN for deviant phonemes but not for deviant prosody. This suggests that MMN parameters (location, amplitude, and latency) are not the same for all types of epilepsy, and are possibly related to seizure type, location, and dysfunction of different $\mathrm{MMN}$ generators. For example, frontal lobe epilepsy with focal seizures may not affect MMN at the mastoids. Thus, due to its focal nature, TLE is a type of epilepsy that can enable us to better understand the mechanisms underlying MMN elicitation, and perhaps give us a reliable electrophysiological index of central auditory processing of both speech and non-speech. In addition, MMN might give us a possible objective measure of short-term auditory memory, auditory discrimination, and the involuntary switch in auditory attention, which may in turn relate to seizure location, prognosis, and degree of rehabilitation. The existing literature provides discrepant accounts of how MMN is affected in children with TLE. Further, different results from speech and non-speech stimuli are obtained. This suggests a different mechanism for the auditory processing of speech and non-speech.

Keeping the above in mind, we propose a protocol for an ERP study based on the hypothesis that the pattern of MMN responses to individual word and pure-tone deviants, which reflect how memory traces are activated in the brain, provides an electrophysiological way of investigating how language is neuronally processed. Moreover, MMN is non-attention demanding and task-free, making it particularly suitable for neurological paediatric populations (such as children with TLE). Nevertheless, further work is required to optimise the paradigm before it can be of clinical value. We therefore invite researchers and clinicians to test it in other types of epilepsy and clinical populations and to share the results.

\section{Suggested Method and Procedure}

Two groups are required, the epilepsy/experimental group (EG) and the control group (CG), matching characteristics such as age, gender, education, mother tongue, and handwriting (if applicable). EG diagnosis would be based on a combination of clinical symptoms, EEG, and structural/functional imaging [22]. Other relevant information might be duration of epilepsy, age of onset, side of epileptic focus (if possible), seizure status, and number and dosage of antiepileptic drugs (AEDs).

Exclusion criteria for both groups would include hearing loss, comorbid psychiatric disease, and hearing or vision problems at the time of the experiment. For the CG, additional exclusion criteria would include a history of developmental disorders, traumatic brain injury (with cognitive consequences or loss of consciousness), convulsions other than simple febrile seizures, and psychiatric disease or epileptic disorder in first-degree relatives. 
In more detail, parents sign consent forms, after being informed of the nature and objective of the experiment. Selected children are fitted with an electrode cap; the EEG would be recorded with a sampling rate above $256 \mathrm{~Hz}$ and a bandwidth between 0.05 and $100 \mathrm{~Hz}$. Electrode reference is averaged ear lobes. Two electrodes are placed above the left eye and below the right eye to monitor the electrooculogram (sweeps with amplitudes exceeding $\pm 70 \mu \mathrm{V}$ due to blinks or eye/face movements are rejected before averaging). Impedance between the electrodes and skin less than $5 \mathrm{k} \Omega$. Post hoc analysis could include bandpass filtering $(0.3-30 \mathrm{~Hz})$, linear detrending of the entire sweep, and baseline correction.

Behavioral pure-tone audiograms (250 to $8000 \mathrm{~Hz}$ ), speech reception threshold (SRT), and monosyllabic discrimination should be obtained to detect hearing loss, using a clinical audiometer (we use an Amplaid A177). All listeners must have hearing thresholds bilaterally of $20 \mathrm{~dB} \mathrm{HL}$ or better [23]. Additionally, otoscopy and acoustic immittance testing might be performed prior to each session in order to rule out abnormal middle-ear status. All listeners must have a normal tympanogram (admittance curve with a single peak between $(-100$ and $+50 \mathrm{daPa})$ and a present ipsilateral acoustic reflex $(500,1000,2000,4000 \mathrm{~Hz}$, $90 \mathrm{~dB} \mathrm{HL}$ ) in the test ear.

The most widely applied stimuli presentation, with the most replicable results, is a binaurally auditory oddball stimulation. Subjects are presented with sequences of three blocks of tones and three blocks of speech stimuli, each containing a stimulus onset asynchrony (SOA) between 500 and $1000 \mathrm{~ms}$. In the tone blocks, the standard stimulus $(1000 \mathrm{~Hz}, 100 \mathrm{~ms}$, rise and fall time $10 \mathrm{~ms})$ is replaced by a frequency deviant $(1100 \mathrm{~Hz}, 100 \mathrm{~ms})$. Speech stimuli blocks consist of digitized (rate $44100 \mathrm{~Hz}$ ) consonantvowel syllables of $175 \mathrm{~ms}$ duration; the standard phoneme is $/ \mathrm{ba} /$ and the deviant $/ \mathrm{pa} /$. These phonemes were selected for this protocol because they differ in place of articulation and thus differ in frequency; the use of a puretone frequency deviant is far the most used and validated stimuli [24-27]. In all single blocks, standard stimuli comprise $80 \%$ of all trials, while deviant stimuli comprise $20 \%$. During recording, subjects should be comfortably seated in an armchair watching a silent DVD or instructed to keep alert with eyes open and focus on a small cross in the center of a computer screen. Additionally, they should be asked to stay calm, avoid any eye/face movement, and to ignore auditory stimuli (reducing attention on the experimental stimuli).

\section{Discussion}

A large number of converging MMN studies support the feasibility of using the MMN as a tool to study deficient auditory perception in children, particularly in clinical pediatric groups with dyslexia, specific language impairment, epilepsy, cochlear implant candidates [13-15,28-32], dysphasia, and specific language impairment [33-35] (but also in uncooperative patients to behavioral measures [36-40]). Several authors have studied MMN elicitation in adults with TLE. Despite abnormality differences, all researchers agree on the mechanism of the dysfunction underlying MMN; they point to electrophysiological evidence for concentration and short-term memory difficulties in TLE patients [19-21,41-43].

However, it is well known that AEDs and benzodiazepines, for example, can have an effect on motor reaction times, latencies, and amplitudes of ERPs $[15,20,44]$. Thus, we believe more reliable results can be achieved in pediatric populations by not introducing pharmacological factors. In further studies, researchers and clinicians should consider the type of medication and the individual doses of the patients tested.

In summary, it seems that the ERP is a powerful tool for revealing cortical abnormalities in TLE patients which have not been well characterized previously by conventional EEG, NMR, or PET. In these terms, MMN seems particularly apt.

The expected results with this protocol might reveal abnormal MMN for speech and non-speech stimuli at temporal and frontocentral sites in TLE children. These results could lead us to new findings on the specific neuronal mechanisms underlying MMN generation. They could improve theories that seek to explain MMN, such as the memory-based model, the predictive model, and the adaptation model, and also give a better understanding of epileptogenesis in general [45-49]. In most cases, language and handedness relate to hemispheric dominance, so if a developmental consequence could be established between seizure side and language deficit, clinicians may be able to prescribe better treatment or rehabilitation for overcoming neurophysiological deficits.

According to Miyajima et al. (2011), TLE in adults shows up as an enhanced frontal MMN and a decrease at the mastoids, suggesting that the MMN might represent cortical regions of hyperexcitability that compensate for epileptic neurone dysfunction in the temporal lobes $[13,20]$. Since speech and non-speech have different underlying mechanisms, differences between MMN elicitation with speech and non-speech stimuli, within the same patient, could indicate which mechanism or MMN generator is affected, making it possible to choose the best rehabilitation program (speech $v s$. non-speech processing, memory, or discrimination). For example, if we compare the results of Miyajima et al. (2011) and Hara et al. (2012), temporal lobe MMN generators appear to be more involved when MMN is elicited by vowel changes than when it is elicited by pure-tone frequency changes. TLE patients showed significantly reduced amplitudes at mastoid sites to speech sounds, but no significant changes to pure-tone sounds. On the other hand, TLE patients showed an enhanced MMN at frontocentral sites to pure-tone sounds, but no significant changes to speech sounds $[20,50]$.

These results support the view that the MMN is generated by separate sources in the frontal and temporal lobes, and that these sources are differentially affected by TLE; they also suggest that speech production requires a stable sensory memory reference in temporal cortices $[51,52]$. Furthermore, if differences within the TLE group are obtained, these may be related to seizure frequency, duration of epilepsy, side of epileptic focus, age of onset, and seizure status. In terms of temporal lobe generators and seizure frequency, 
the lower and later is the MMN to speech sounds, the worse the prognosis. On the other hand, the MMN can be useful for monitoring the remission of seizures and the progress of language rehabilitation (some amazing results have been obtained in aphasic patients). However, few follow-up studies have revealed a correlation between MMN amplitude and progressive improvement in speech comprehension tests from 10 days to 6 months after stroke [13,37-39,53-55].

\section{The Hypothesis}

The existing literature provides discrepant accounts of how the MMN is affected in children with TLE. Regarding published results of MMN applied to dyslexia and specific language impairments, although similar language and memory deficits may be present in TLE, differences in MMN elicitation to speech and non-speech stimuli have been obtained. This suggests a different mechanism for the auditory processing of speech and non-speech, and also to underlying neurophysiological differences between disorders.

We hypothesize that children with TLE may have abnormal MMN amplitude, morphology, and latency for speech and non-speech stimuli across electrode locations, and those abnormalities may be associated the location and frequency of epileptic seizures. A secondary motivation is to understand how the hemispheric specializations for speech and non-speech stimuli are compromised in childhood TLE.

According to the model of central auditory processing proposed by Näätänen (1990), explaining attention and automaticity in auditory processing, the expected results could contribute to a better understanding of the neuropsychophysiology of MMN and how it affects central sound processing, thus linking sound perception and sensory memory tightly together $[11,12,15,45,56]$. As a clinically non-invasive tool, MMN seems well suited to the pediatric population, and could be a great asset as an electrophysiological indicator of neuropsychological aspects of auditory and language processing (namely, attention and sensory memory). A lot of work remains to be done, but perhaps in the future we will be able to apply a common MMN index to different clinical populations, making it a reliable clinical tool.

\section{Acknowledgements}

We appreciate the advice and expertise of Dr Victor Osey-Lah (Portsmouth Hospital/NHS).

\section{Conflicts of Interest Statement}

There are no financial, relationship, or organizational conflicts of interests that could bias the authors.

\section{References:}

1. Helmstaedter C, Kurthen M. Memory and epilepsy - characteristics, course, and influence of drugs and surgery. Curr Opin Neurol, 2001; 14: 211-16.

2. Mantoan M, da Silva T, Alonso N, Noffs M, Marques C, Rios L et al. Neuropsychological assessment and quality of life in patients with refractory temporal lobe epilepsy related to hippocampal sclerosis. J Epilepsy Clin Neurophysiol, 2006; 12(4): 201-6.

3. Mintzer S, Cendes F, Soss J, Andermann F, Engel Jr J, Dubeau F et al. Unilateral hippocampal sclerosis with contralateral temporal scalp ictal onset. Epilepsia, 2004; 45(7): 792-802.

4. Ballaban-Gil K. Language disorders and epilepsy. In: Pedley TA, Meldrum BS. (eds.). Recent Advances in Epilepsy.Churchill Livingstone, Edinburgh, 1995; 205-20.

5. Loring DW, Hermann BP, Lee GP, Drane DL, Meador KJ. The memory assessment scales and lateralized temporal lobe epilepsy. J Clin Psychol, 2000; 56: 563-70.

6. Hendriks MP, Aldenkamp AP, Alpherts WC, Ellis J, Vermeulen J, van der Vlugt H. Relationships between epilepsy-related factors and memory impairment. Acta Neurol Scand, 2004; 110: 291-300.

7. Butler CR, Zeman AZ. Recent insights into the impairment of memory in epilepsy: transient epileptic amnesia, accelerated long-term forgetting and remote memory impairment. Brain, 2008; 131(Pt.9): 2243-63.

8. McCagh J, Fisk JE, Baker GA. Epilepsy, psychosocial and cognitive functioning. Epilepsy Res, 2009; 86: 1-14.

9. Tomé $\mathrm{D}$, Jesus E, Esteves $\mathrm{M}$. Auditory middle latency response in epilepsy. Sinapse, 2011; 11: 5-11.

10. Näätänen R, Gaillard AWK, Mäntysalo S. Early selective-attention effect on evoked potential reinterpreted. Acta Psychol, 1978; 42: 313-29.
11. Näätänen R, Paavilainen $P$, Alho K, Reinikainen K, Sams M. The mismatch negativity to intensity changes in an auditory stimulus sequence. Electroencephalogr Clin Neurophysiol Suppl, 1987; 40: 125-31.

12. Näätänen R. The perception of speech sounds by the human brain as reflected by the mismatch negativity (MMN) and its magnetic equivalent (MMNm). Psychophysiology, 2001; 38: $1-21$.

13. Näätänen R, Kujala T, Escera C, Baldeweg T, Kreegipuu K, Carlson $\mathrm{S}$ et al. The mismatch negativity $(\mathrm{MMN})$ - a unique window to disturbed central auditory processing in ageing and different clinical conditions. Clin Neurophysiol, 2012; 123(3): $424-58$.

14. Nääänen R: Mismatch negativity: clinical research and possible applications. Int J Psychophysiol, 2003; 48: 179-88.

15. Näätänen R, Paavilainen $P$, Rinne $T$, Alho $K$. The mismatch negativity (MMN) in basic research of central auditory processing: a review. Clin Neurophysiol, 2007; 118: 2544-90.

16. Liasis A, Towell A, Boyd S. Intracranial auditory detection and discrimination potentials as substrates of echoic memory in children. Cognit Brain Res, 1999; 7: 503-6.

17. Giard MH, Perrin F, Pernier J, Bouchet P. Brain generators implicated in processing of auditory stimulus deviance: a topographic event-related potential study. Psychophysiology, 1990; 27: $627-40$.

18. Escera C, Corral MJ: Role of mismatch negativity and novelty-P3 in involuntary auditory attention. J Psychophysiol, 2007; 21: 251-64.

19. Boatman DF, Trescher WH, Smith C, Ewen J, Los J, Wied HM et al. Cortical auditory dysfunction in benign rolandic epilepsy. Epilepsia, 2008; 49: 1018-26. 
20. Miyajima M, Ohta K, Hara K, Iino H, Maehara T, Hara M et al. Abnormal mismatch negativity for pure-tone sounds in temporal lobe epilepsy. Epilepsy Res, 2011; 94: 149-57.

21. Honbolygó F, Csépe V, Fekésházy A, Emri M, Márián T, Sárközy $\mathrm{G}$ et al. Covering evidences on language impairment in Landau-Kleffner Syndrome revealed by behavioural and brain activity measures: a case study. Clin Neurophysiol, 2006; 117: 295-305.

22. Commission on Classification and Terminology of the International League Against Epilepsy: Proposal for revised classification of epilepsies and epileptic syndromes. Commission on Classification and Terminology of the International League Against Epilepsy. Epilepsia, 1989; 30: 389-99.

23. Bureau International d'Audiophonologie (BIAP): Recommendation BIAP no. 02/1 bis. Classification audiométrique des deficiencies auditives. 2005; http://www.biap.org/recom02-1.htm [in French]

24. Martin B, Sigal A, Kurtzberg D, Stapells D. The effects of decreased audibility produced by high-pass noise masking on cortical event-related potentials to speech sounds /ba/ and / da/. J Acoust Soc Am, 1997; 101: 1585-99.

25. Martin B, Kurtzberg D, Stapells D. The effects of decreased audibility produced by high-pass noise masking on $\mathrm{N} 1$ and the mismatch negativity to speech sounds /ba/ and /da/. J Speech, Lang Hear Res, 1999; 42: 271-86.

26. Hari R, Hämäläinen M, Ilmoniemi R, Kaukoranta E, Reinikainen K, Salminen J et al. Responses of the primary auditory cortex to pitch changes in a sequence of tone pips: neuromagnetic recordings in man. Neurosci Lett, 1984; 50: 127-32.

27. Escera C, Corral MJ, Yago E. An electrophysiological and behavioral investigation of involuntary attention towards auditory frequency, duration and intensity changes. Cogn Brain Res, 2002; 14: 325-32.

28. Kujala T, Näätänen R. The mismatch negativity in evaluating central auditory dysfunctions in dyslexia. Neurosci Biobehav Rev, 2001; 25: 535-43.

29. Liasis A, Bamiou DE, Boyd S, Towell A. Evidence for a neurophysiologic auditory deficit in children with benign epilepsy with centro-temporal spikes. J Neural Trans, 2006; 113: 939-49.

30. Marler JA, Chamolin CA, Gillam RB. Auditory memory for backward masking signals in children with language impairment. Psychophysiology, 2002; 39: 767-80.

31. Groenen P, Snik A, van der Broek P. On the clinical relevance of mismatch negativity: results from subjects with normal hearing and cochlear implant users. Audiol Neuro-Otology, 1996; 1: 112-14.

32. Wable J, van der Abbeele T, Gallégo S, Frachet B. Mismatch negativity: a tool for the assessment of stimuli discrimination in cochlear implant subjects. Clin Neurophysiol, 2000; 111: 743-51.

33. Korpilahti P, Lang HA. Auditory ERP components and mismatch negativity in dysphasic children. Electroencephalogr Clin Neurophysiol, 1994; 91(4): 256-64.

34. Uwer R, Ronald R, von Suchodoletz W. Automatic processing of tones and speech stimuli in children with specific language impairment. Dev Med Child Neurol, 2002; 44: 527-32.

35. Metz-Lutz M-N, Philippini M. Neuropsychological findings in rolandic epilepsy and Landau-Kleffner syndrome. Epilepsia, 2006; 47: S71-75.

36. Hough MS, Downs CR, Cranford J, Givens G. Measures of auditory processing in aphasia: behavioural and electrophysiological analysis. Aphasiology, 2003; 17(2): 159-72.
37. Ilvonen T, Kujala T, Kozou H, Kiesiläinen A, Salonen O, Alku P et al. The processing of speech and non-speech sounds in aphasic patients as reflected by the mismatch negativity (MMN). Neurosci Lett, 2004; 366: 235-40.

38. Särkämö T, Pihko E, Laitinen S, Forsblom A, Soinila S, Mikkonen $\mathrm{M}$ et al. Music and speech listening enhance the recovery of early sensory processing after stroke. J Cognitive Neurosci, 2010a; 22: 2716-27.

39. Särkämö T, Tervaniemi M, Laitinen $S$, Forsblom A, Soinila $S$, Mikkonen $\mathrm{M}$ et al. Music listening enhances cognitive recovery and mood after middle cerebral artery stroke. Brain, 2008; 131: 866-76.

40. Robin D, Tranel D, Damasio H. Auditory perception of temporal and spectral events in patients with focal left and right cerebral lesions. Brain Lang, 1990; 39: 539-55.

41. Gene-Cos N, Pottinger R, Barrett G, Trimble MR, Ring HA. A comparative study of mismatch negativity (MMN) in epilepsy and non-epileptic seizures. Epileptic Disord, 2005; 7: 363-72.

42. Rosburg T, Trautner P, Dietl T, Korzyukov OA, Boutros NN, Schaller $\mathrm{C}$ et al. Subdural recordings of the mismatch negativity (MMN) in patients with focal epilepsy. Brain, 2005; 128 : 819-28.

43. Piazzini A, Turner K, Chifari R, Morabito A, Canger R,Canevini MP. Attention and psychomotor speed decline in patients with temporal lobe epilepsy: a longitudinal study. Epilepsy Res, 2006; 72: 89-96.

44. Lagae L. Cognitive side effects of anti-epileptic drugs. The relevance in childhood epilepsy. Seizure, 2006; 5: 235-41.

45. Näätänen $R$. The role of attention in auditory information process as revealed by event-related potentials and other brain measures of cognitive function. Behav Brain Sci, 1990; 13: 201-88.

46. Winkler I. Interpreting the mismatch negativity. J Psychophysiol, 2007; 21(3-4): 147-63.

47. May P, Tiitinen H. Mismatch negativity (MMN), the devianceelicited auditory deflection, explained. Psychophysiology, 2010; 47: 66-122.

48. Näätänen R, Winkler I. The concept of auditory stimulus representation in cognitive neuroscience. Psychol Bull, 1999; 125: $826-59$.

49. Jääskeläinen IP, Ahveninen J, Bonmassar G, Dale AM, Ilmoniemi RJ, Levänen $S$ et al. Human posterior auditory cortex gates novel sounds to consciousness. Proc Natl Acad Sci USA, 2004; 101: 6809-14.

50. Hara K, Ohta K, Miyajima M, Hara M, Iino H, Matsuda A et al. Mismatch negativity for speech sounds in temporal lobe epilepsy. Epilepsy Behav, 2012; 23: 335-41.

51. Shestakova A, Brattico E, Huotilainen M, Galunov V, Soloviev A, Sams $M$ et al. Abstract phoneme representations in the left temporal cortex: magnetic mismatch negativity study. Neuroreport, 2002; 13: 1813-16.

52. Shestakova A, Huotilainen M, Ceponiene R, Cheour M. Eventrelated potentials associated with second language learning in children. Clin Neurophysiol, 2003; 114: 1507-12.

53. Ilvonen T-M, Kujala T, Kiesiläinen A, Salonen O, Kozou H, Pekkonen E et al. Auditory discrimination after left hemisphere stroke: an MMN follow-up study. Stroke, 2003; 34: 1746-53.

54. Ilvonen T-M, Kujala T, Tervaniemi M, Salonen O, Näätänen R, Pekkonen E. The processing of sound duration after left hemisphere stroke: event-related potential and behavioral evidence. Psychophysiology, 2001; 38: 622-28. 
55. Pettigrew C, Murdoch B, Kei J, Ponton C, Alku P, Chenery H. The mismatch negativity (MMN) response to complex tones and spoken words in individuals with aphasia. Aphasiology, 2005; 19(2): 131-63.
56. Näätänen R, Alho K. Mismatch negativity: the measure for central sound representation accuracy. Audiol Neuro-Otol, 1997; 2: 341-53. 